\title{
Faba Bean (Vicia faba L.), A Promising Grain Legume Crop of Bangladesh: A Review
}

\author{
Swapan Kumar Paul', Dipali Rani Gupta ${ }^{2}$
}

10.18805/ag.R-203

\begin{abstract}
Faba bean is one of the multi-purpose oldest crop which is used as a source of dietary protein in human, as fodder and forage for livestock, feed for poultry and for available nitrogen for the biosphere. It is cool season grain legume that is grown in large areas in various countries in the world including a limited locality in Bangladesh. Diverse ecosystem benefits are expected from inclusion faba bean in cropping systems. This article reviews the published work mentioning potential uses of faba bean world-wide, challenges and its cultivation possibilities in Bangladesh.
\end{abstract}

Key words: Constrains, Faba bean, Importance, Possibility, Status.

Faba bean (Vica faba L.) is a widely popular grain legume that is used as human food and animal feed for its high nutritional quality (Cazzato et al., 2012; Yasmin et al., 2020). It is one of the most vital winter crops for human consumption in the central part of the world (Yadav et al., 2017). The crop contributes to soil health improvement through biological $\mathrm{N}$-fixation (Gasim and Link, 2007; Rubiales and Mikic, 2015). It is also used as an excellent component of crop rotations, something that has been very much ignored in recent cropping when there is a crucial need to reduce the impact of chemical fertilizers on the environment. Due to its numerous uses, high nutritional quality and capability to grow over a wide range of agro-climatic conditions, faba bean is appropriate for sustainable agriculture in many neglected areas and the crop has received greater global attention in recent years (Nadal et al., 2003; Gasim et al., 2015). Faba bean can continue their growth and development at extreme temperatures (Multari et al., 2015).

In Bangladesh, faba bean (Vicia faba L.) is grown in some limited locality which is well known as Kalimator, Baklakalai, Bhograkalai, etc. (Sheikh et al., 2020; Paul et al., 2021). It is grown in winter season as other pulses after the harvesting of transplanted Aman rice with minimum tillage or sometimes directly sown in low lying areas as a relay crop with Aman rice (Biswas, 1988; Paul et al., 2021). The increasing demand for protein in human and animal consumption and the high cost of animal sources such as meat and fish have resulted in increased demand for legumes as a source of dietary protein and calories. Protein deficiency in human diet often leads to protein-energymalnutrition causing various forms of anemia (Shukla and Mishra, 2020). We are accounting for chronic protein deficiency for the increasing population; the traditional legumes (lentil, mungbean, grass pea, peas, chickpea and black gram) are grown in Bangladesh. These legumes are low yielding and very much susceptible to insect pests and diseases and requires more agricultural practices.
'Department of Agronomy, Bangladesh Agricultural University, Mymensingh 2202, Bangladesh.

${ }^{2}$ Institute of Biotechnology and Genetic Engineering (IBGE), Bangabandhu Sheikh Mujibur Rahman Agricultural University, Gazipur 1706, Bangladesh.

Corresponding Author: Swapan Kumar Paul, Department of Agronomy, Bangladesh Agricultural University, Mymensingh 2202, Bangladesh. Email: skpaul@bau.edu.bd

How to cite this article: Paul, S.K. and Gupta, D.R. (2021). Faba Bean (Vicia faba L.), A Promising Grain Legume Crop of Bangladesh: A Review. Agricultural Reviews. 42(3): 292-299. DOI: $10.18805 /$ ag.R-203.

Submitted: 21-04-2021 Accepted: 12-07-2021 Online: 31-07-2021

Therefore, now a days underutilized crop faba bean is showing its promise for its large size, high yielding, resistance to pests and diseases, and requires less input. So, the crop would undoubtedly play an important role in crop diversification as well as protein supplementation programs in Bangladesh.

\section{Global aspect and trend of Faba bean cultivation}

Faba bean is currently produced in more than 66 countries over the world (Merga et al., 2019). Twenty years of data (2000 to 2019) showed that Asia is world's leading continent covers $41 \%$ production followed by Africa and Europe with the production (Fig 1). Fig 2 shows that China (1.74 million tons), Ethiopia (1.01 million tons), United Kingdom (0.55 million tons), Australia (0.33 million tons), France (0.18 million tons), Sudan (0.16 million tons), Germany (0.16 million tons), Italy ( 0.13 million tons), Lithunia ( 0.13 million tons) and Egypt (0.10 million tons) are the top ten faba bean producers in the world in 2019 (FAO, 2021). Compared to the year 2000, the area cultivated for faba bean production increased slightly from 2.51 to 2.58 million ha in 2019 . However, the total production quantity of faba bean increased apparently from 3.78 to 5.43 million tons in 2019 
from 2000 (Fig 3). In between 2000 and 2019 the area of faba bean cultivation decreased in 2006, 2014 and 2019 compared to subsequent previous year although production decreased in respect to area in 2006 and 2014, whereas in 2019 production increased compared to 2018 even though

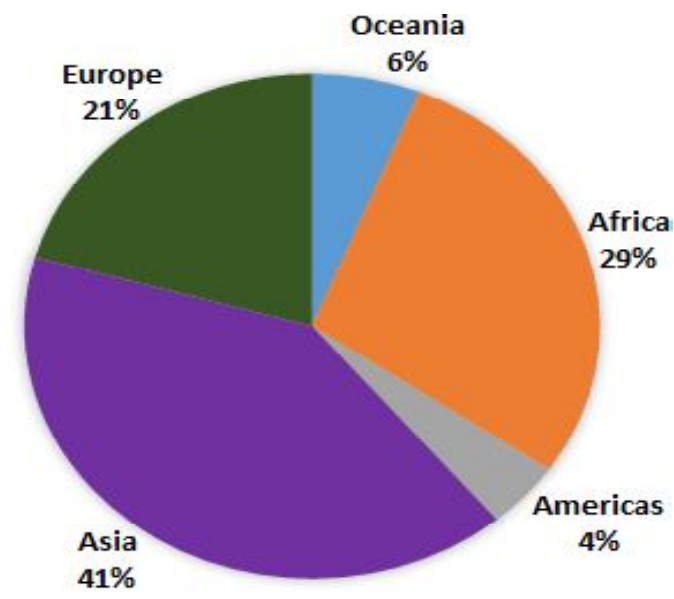

Fig 1: Globally mean (20 years) annual production share of faba bean by region from 2000 to 2019 , Source: FAO (2021).

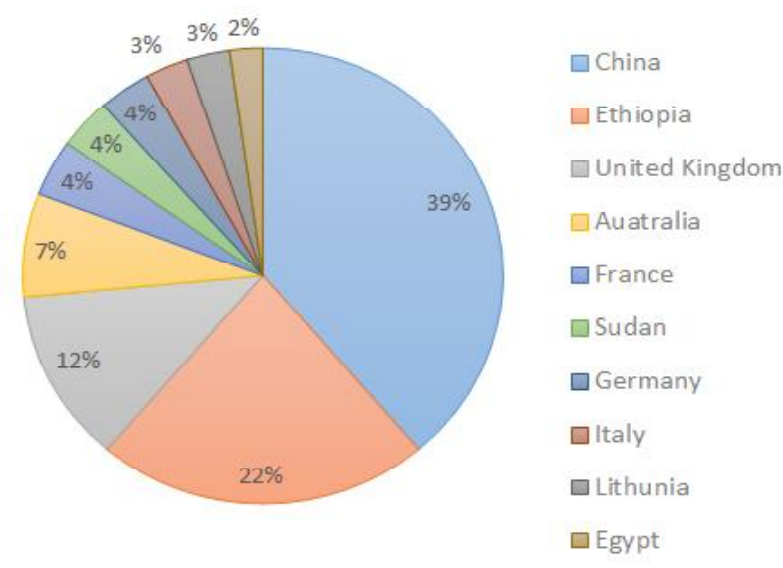

Fig 2: Relative importance of the 10 leading fababean producing countries during 2019 cropping year. Source: FAO (2021). area decreased (Fig 3). The global pulse crops data of 2010 to 2019 , revealed that the annual average area 3.38 to 4.55 million ha and production 4.74 to 6.0 million tons (FAO, 2021). Globally, the areas cultivated for faba bean have decreased highly from 5.40 million ha (1961) to 2.58 million ha (2019) and as against this, the average yield bean has increased 0.90 t ha $^{-1}(1961)$ to $2.11 \mathrm{t} \mathrm{ha}^{-1}$ (2019) (FAO, 2021). Despite the decreasing acreage, however, productivity per area has tended to increase, due to reduced susceptibility to abiotic and biotic stresses (Link et al., 2010; Sillero et al., 2010; Singh et al., 2012; Karkanis et al., 2018). The statistical data on faba bean acreage and production are not available in Bangladesh. Although pulse crop covered an area of 0.36 million hectares with the production of 0.16 million tons including a very little contribution from faba bean in Bangladesh (BBS, 2020).

\section{Importance of faba bean}

Nutritional values

Faba bean (Vicia faba L.) is a unique legume crop because of its very rich nutrient content which also serves as an outstanding source of proteins, complex carbohydrates, dietary fibre, choline, lecithin, minerals and secondary metabolites such as phenolics. Interestingly, in contrast to cereals, faba bean is found to contain a high level of lysine and arginine, which may complement the low levels of those in cereals. Faba bean could be used in combination with other plant-based foods to improve the quality and quantity of the proteins provided in a meal (Multari et al., 2015). Much consideration is now being compensated on the antioxidant capacity of the flavonoids and the phenolics (Sinha et al., 2013). Kumar et al. (2015) found the different nutritional parameters in variable concentration among different germplasms of faba bean viz. total soluble protein $20-32 \%$, free amino acids $188-348 \mathrm{mg} / 100 \mathrm{~g}$, starch $27-33 \%$, reducing sugars $85-188 \mathrm{mg} / 100 \mathrm{~g}$, non-reducing sugars $0.7-1.7 \%$ and total soluble sugars $0.8-1.9 \%$. Mortuza et al. (2009) found from the chemical analyses of faba bean contains protein $(30.57 \%)$, crude fat $(3.22 \%)$ and fibre $(2.73 \%)$, ash $(3.61 \%)$ and carbohydrate (59.87\%) and essential amino acids with lower methionine/cystine and higher lysine content. Faba

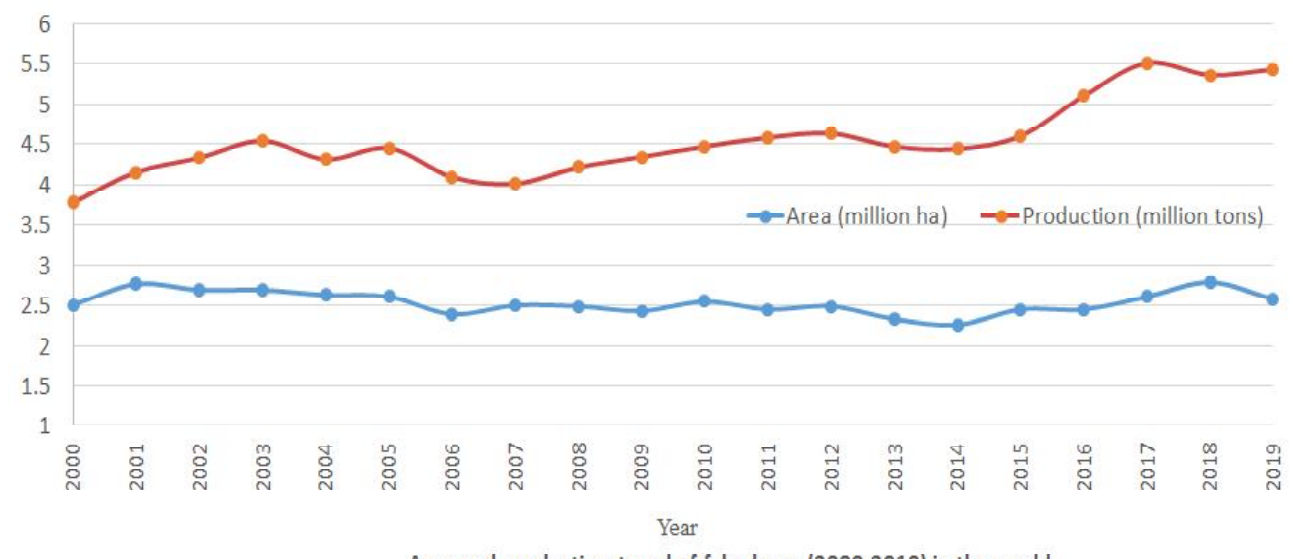

Area and production trend of faba bean (2000-2019) in the world

Fig 3: Globally areas cultivated for faba bean production and amount of production from 2000 to 2019. Source: FAO (2021). 
Faba Bean (Vicia faba L.), A Promising Grain Legume Crop of Bangladesh: A Review

bean is a rich source of fiber and non-nutrient secondary metabolites shown to be beneficial to human health (Aune et al., 2011). However, the chemical composition is strongly influenced by genotype, environment as well as management practices (Mona et al., 2011; Cazzato et al., 2012; Witten et al., 2015; Karkanis et al., 2018).

Faba bean seed contains phytic acid, saponins, lectins, alkaloids, and others, which have anti-nutritional functions and reduces the digestibility of seeds (Gupta, 1987). However, some domestic approaches such as soaking and cooking at high temperatures markedly reduce and often totally abolish them from the seed (Luo et al., 2009). Tannins are phyto-chemicals abundant in faba beans which are one of the main anti-nutritional factors that reduce the bioavailability of proteins and minerals (Sinha et al., 2013). They negatively affect the digestibility of proteins present in the food matrix (Papadopoulou and Frazier, 2004). As tannin are mainly located in the seed hulls (Helsper et al., 1993), the process of dehulling leads to a drastic reduction (Alonso et al., 2000), while soaking and autoclaving inactivate trypsin inhibitor activity (Luo and Xie, 2013; Shi et al., 2017).

\section{Uses as food and feed}

Faba bean is popular worldwide for its nutritional value and vast area of uses. It is used as human food in unindustrialized countries and as animal feed, mainly for pigs, horses, poultry and pigeons in developed countries (Singh and Bhatt, 2012a). In Bangladesh, it is usually used as a dal (soup) for humans. It can be used as a vegetable, green or dried, fresh or canned (Gasim and Link, 2007). It is one of the most important winter crops for human consumption in the Middle East (Martin et al., 1991). Faba bean has been considered as a meat extender or substitute and as a skim-milk substitute (Oplinger, 1982). It also faba bean cultivated for green manure, but more generally for store feed (Singh and Bhatt, 2012b). Faba bean seed contains low LGC (Least gelation concentration) value indicates that faba bean has a larger capacity to form gel than other seed flours (Sathe et al., 1982, Oshodi and Adeladun 1993, Kaur and Singh, 2007) and consequently may be an asset of faba bean for the making of curd, pudding or as an additive to other gelforming materials in food products. Large-seeded immature beans are eaten as a vegetable after boiling and roasted seeds are eaten like peanuts in India and other countries (Yitayih and Azmeraw, 2017). The high protein content of faba bean seeds brands this seed well adapted to poultry nutrition. When faba bean is comprised of levels as high as $250 \mathrm{~g} / \mathrm{kg}$ in broiler diets, it can substitute soybean meal in a huge portion. However, in different animal species, it has been detected that extreme diets covering about $50 \%$ faba beans significantly reduced the absorption of $\mathrm{Zn}$ and $\mathrm{Mn}$ (Rubio et al., 1994). Proskina and Cerina (2017) reported that adding legume (field peas and faba beans) to the broiler feed ration resulted in a significant live weight increase (5.74$11.95 \%$ ) at the selling age, a decrease in the feed conversion ratio by $0.61-6.06 \%$, and decrease in the product unit cost (15.34-37.06\%) as well as an increase in the production eficiency factor (8.70-48.54), compared with the control group.

\section{Medicinal uses}

Faba bean has been endorsed with its certain medicinal values and in this direction, research is going on the potential use of faba bean as a treatment in Parkinson's disease. People with Parkinson's disease are unable to produce dopamine, which helps as a chemical messenger in the brain and helps regulate important motor and cognitive functions (Sinha, 2012). Commonly Parkinson's disease patients are treated with synthesized L-Dopa. Synthesized L-Dopa is expensive and often related to a variety of side effects including nausea, vomiting, low blood pressure, drowsiness, and restlessness (Patil et al., 2013). Therefore, consuming natural sources of L-Dopa to avert potential side effects has been recommended (Singh et al., 2013; Patil et al., 2013). Faba bean is a good source of levodopa (L-dopa), a natural precursor for the various neurotransmitters like dopamine (Upadhvay et al., 2014). L-Dopa, a precursor of dopamine currently used as a major ingredient in treating Parkinson's disease and hormonal imbalance (Surwase et al., 2012; Hu et al., 2015; Ramirez-Moreno et al., 2015; Etemadi et al., 2018). L-dopa is also a natriuretic (urinary excretion of sodium) agent, which might help in controlling hypertension (Jambunathan et al., 1994). Some also use faba beans as a natural alternative to drugs like Viagra, citing a link between L-dopa production and the human libido (Hulse, 1994). It is estimated that the annual world demand for L-Dopa is about 250 tons with a market value of about $\$ 101$ billion (Patil et al., 2013). Cultivation of crops that are rich in natural L-Dopa to overwhelmed side effects and the high cost of production of synthetic L-Dopa thus seems justifiable (Singh et al., 2013; Patil et al., 2013). Fru"hbeck et al. (1997) noted that beside protein and energy supply, effects of faba beans-enriched diet have been described in humans where significant decrease in plasma LDL (low-density lipoprotein) cholesterol levels. Faba bean and derivatives could represent a suitable food in treatment of diabetics, in hypertension and may help to prevent cardiovascular disease (Madar and Stark, 2002). The antioxidant, antiinflammatory and anti-diabetic properties of faba bean could be involved (using polyphenols) in the protection against the development of human diseases (Turco et al., 2016).

\section{Soil health improvement}

The amount of $\mathrm{N}$ fixed by the symbiotic relationship between legumes and the soil rhizobia bacteria is determined by the relative reliance of the crop on biological nitrogen fixation for growth and the amount of $\mathrm{N}$ accumulated by the crop over the growing season (Jensen and Hauggaard-Nielsen, 2003). Numerous environmental factors are hindering the agricultural production, for example the calcareous soils suffering from ferric and phosphoric deficiencies. In those 
soils, legumes were measured as an alternative solution to retrieve a fertile soil without the abusive use of chemical fertilizers (Wissal et al., 2020). Faba bean is the highest nitrogen-fixing annual legume making it an excellent rotational crop. It can fix uphill of $90 \%$ of their nitrogen desires, which means less nitrogen fertilizer needs to be applied. There has been a certain subjective signal that cereal crops succeeding faba bean can see a yield upsurge of 10 to $15 \%$. This could be a result of the nitrogen that is slowly released from the faba bean stubble. Murinda and Saxena (1985) reported that faba bean fixes extra nitrogen (135 kg N ha-1) than lentil and chickpea. Nitrogen sources from $\mathrm{N}_{2}$ fixation and soil will generally be utilized more competently since the greater competitive ability of the cereal element for soil mineral $\mathrm{N}$ (or fertilizer $\mathrm{N}$ ) results in reduced uptake of soil $\mathrm{N}$ and higher requirement upon $\mathrm{N}_{2}$ fixation by intercropped faba bean compared to a faba bean crop (Hauggaard-Nielsen et al., 2008). Faba bean used as green manure which is a keystone for improving the sustainability of agro-ecosystems due to their beneficial impacts on fertility building (Álvarez-lglesias et al., 2015). Incorporating legume residues into the soil as green manure improves soil properties such as organic matter content, bulk density, porosity and field capacity (Mandal et al., 2003; Salahin et al., 2013; Adekiya et al., 2017) and consequently increase yield of field crops (Bilalis et al., 2012; O'Donovan et al., 2014).

\section{Used as control biotic agents}

Integrated weed control is essential for successful crop production. The seedling stage of faba beans is poor competitors with weeds (Ali et al., 2000). Álvarez-Iglesias et al. (2014) reported that biomass of faba bean is a promising material for weed control in sustainable cropping systems because faba bean aqueous extracts significantly inhibited the germination and early growth of weeds thus enhances crop growth. Kaletha et al. (1996) and NavaRodríguez et al. (2005) confirmed the in vitro effects of faba bean aqueous leachates and obtained promising allelopathic effects on weeds and crops. If faba bean aqueous extracts used as a potential herbicide for its use in the field, it is basic to ensure its capability of controlling most weeds without damaging the crop (Álvarez-Iglesias et al. (2014). The major insect pest and diseases reduce the quantity and quality of faba bean. Black bean aphid (Aphis fabae L.) is devastating pest of faba bean causing great yield loss (Subedi et al., 2018) through direct feeding damage and transmit plant viruses (Nuessly et al., 2004). Aqueous leaf extracts of faba bean have insecticidal and repellent properties that could be used as an alternative of chemical insecticides in an integrated pest management program to Aphis fabae (Meradsi and Laamari, 2016). Peyvast and Khorsandi (2007) reported that different parts (flowers, leaf, seed and seed hull) of faba bean (broad bean) extracts could produce relative highly antimicrobial activity against various bacteria. Leaf extract in distilled water showed higher antibacterial activity against gram positive bacteria Bacillus sabtilis, Staphylococcus aureus, Micococcus pyogenes and gram negative Escherichia coli, Shigella sp. and Serratia marcescens.

\section{Major challenges and opportunities of faba bean cultivation in Bangladesh}

Lack of potential variety is the key constraints of faba bean cultivation in Bangladesh. Although so many genotypes are available sporadically over the country but not yet recommended nationally considering agroclimatic conditions. Besides, yield potential of faba bean highly responsive to both abiotic and biotic agents. Their relative importance, however, varies depending on the agroecological conditions of the crop production. The main abiotic stresses in Bangladesh include early cold in the crop season, drought at various stages of growth and heat during the reproductive growth and pod filling stages. Salinity also constraints of the production of faba bean in the vast coastal areas of Bangladesh.

Weed is the major constraints that reduces yield loss of faba bean in Bangladesh. The major insect pest and disease which reduces the production and quality of faba bean are aphids, mite, pod borer and thrips. Various leaf fungal diseases viz. chocolate spot, blight, rust, powdery mildew along with root and stem rots and pod spots are very common in faba bean crop in Bangladesh. Root rot and stem rot hampers crop growth properly thus subsequently damage the crop. Rust appears as orange-brown pustules with a light green halo on leaves, which can spread to stems and pods quickly in faba bean crop and drastically damages the faba bean field. Long periods of high humidity and high temperature is very common in some agro-ecological zones of Bangladesh during pod formation stage which promote the switch from a non-aggressive phase to an aggressive phase of the different leaf diseases like chocolate spot, blight and rust thus damages the foliage, limits photosynthetic activity and hamper faba bean production in Bangladesh.

Bangladesh is self-sufficient in grain crop production although it is quoted as one of the most vulnerable countries to climate change due to its geographical position. Now a day's nutritional security is the main issue and challenges for the researchers of Bangladesh. Most of the low income people of Bangladesh fulfill their protein requirements through pulses. Over growing population and low yield of pulses expanded the gape of national demand. But due to the ever-increasing demand and import of pulses, Bangladesh has to spend on valuable hard-earned foreign currency (average USD 301,200.00) every year (Bangladesh Bank, 2021). One of the possible ways to narrow down this gap between demand and supply could be increased through popularizing the underutilized faba bean cultivation. Faba bean can only be grown on diver's agro-climatic conditions successfully, but it can also be produced on residual soil moisture, relatively more tolerant to biotic and abiotic stress, with minimum input (Singh and Bhatt, 2012b). Less productive 1.0 million ha Char lands (river basins) 
(Karim et al., 2017), plain lands of hilly areas and unutilized land of drought prone areas of northern districts can be brought under faba bean cultivation. Nutritional properties of faba bean as well as it's productivity that too with less agricultural inputs with other important pulse crops, it stands at par. It is an excellent source of protein, carbohydrates, and various minerals. Bangladesh has immense potentiality for faba bean cultivation which can take the production of pulses to a satisfactory level and farmers should be accustomed to the potentiality for wide-ranging expansion for their nutritional security.

\section{CONCLUSION}

Faba bean is a valuable multi-purpose crop that can be grown elsewhere in Bangladesh including low fertile soils, char lands, plain lands of hilly areas and drought prone areas with relatively low inputs compared to other legumes. Its nutritional and medicinal values can keep the everincreasing population health through increase production at a satisfactory level. This crop can be suggested also as poultry feed and fish meal as two sectors of Bangladesh emerged nowadays. Being so incredible crop, integrating faba bean in diversification program through various cropping systems improves natural soil fertility and subsequently reduces the consumption of nitrogenous fertilizer. Bangladesh has no recommended faba bean varieties although germplasms are available across the country. Their nutrient composition and tolerance capability of biotic and abiotic stress are not same. Therefore, collection of germplasm and characterize their phenological, morphological, physiological and biochemical traits of faba bean is necessary that will contribute to breeding purposes and its adaptation in the target environments of Bangladesh.

\section{ACKNOWLEDGEMENT}

S.K. Paul extends his thanks to Bangladesh Agricultural University Research System (BAURES) for financial support (2018/333/BAU) to conduct the research on faba bean.

\section{REFERENCES}

Adekiya, A.O., Agbede, T.M., Aboyeji, C.M., Dunsin, O. and Ugbe, J.O. (2017). Green manures and NPK fertilizer effects on soil properties, growth, yield, mineral and vitamin $\mathrm{C}$ composition of okra [Abelmoschus esculentus (L.) Moench]. Journal of the Saudi Society of Agricultural Sciences. 18(2): 218-223. https://doi.org/10.1016/j.jssas.2017. 05.005.

Ali, M., Joshi, P.K., Pandey, S., Asokan, M., Virmani, S.M. et al. (2000). Legumes in the Indo-Gangetic Plain of India. [Johansen, C., et al. Eds.]. ICRISAT, Patancheru-502324, AP. India and Ithaca, New York, USA: Cornell University. pp. 35-70.

Álvarez-Iglesias, L., Puig, C.G., Garabatos, A., Reigosa MJ. and Pedrol, N. (2014). Vicia faba aqueous extracts and plant material can suppress weeds and enhance crops. Allelopathy Journal. 34: 299-314.
Alonso, R., Aguirre, A. and Marzo, F. (2000). Effects of extrusion and traditional processing methods on antinutrients and in vitro digestibility of protein and starch in faba and kidney beans. Food Chem. 68: 159-165. https://doi.org/10.1016/ S0308- 8146(99)00169-7.

Álvarez-Iglesias, L., Revilla, P., Cavaleiro, C., Reigosa, M.J. and Pedrol, N. (2015). Crop legumes for weed control: the case of faba bean (Vicia faba L.). Eucarpia International Symposium on Protein Crops. Pontevedra. 4-7 May, Spain.

Aune, D., Chan, D.S., Lau, R., Vieira, R., Greenwood, D.C., Kampman, E. and Norat, T. (2011). Dietary fibre, whole grains and risk of colorectal cancer: systematic review and doseresponse meta-analysis of prospective studies. BMJ. 343: d6617. https://doi.org/10.1136/bmj.d6617.

Bangladesh Bank. (2021). https://www.ceicdata.com/en/bangladesh /trade-statistics-imports-by-commodity-bangladesh-bank/ imports-pulses-all-sorts.

BBS (Bangladesh Bureau of Statistics) (2020). Yearbook of Agricultural statistics. BBS, Ministry of Planning, Government of the People's Republic of Statistics and Informatics Division, Bangladesh, Dhaka. p. 140.

Bilalis, D., Karkanis, A., Sidiras, N., Travlos, I., Efthimiadou, A., Thomopoulos, P. and Kakabouki, I. (2012). Maize and legumes root growth and yield as influenced by organic fertilization, under mediterranean environmental conditions. Romanian Agricultural Research. 29: 211-217.

Biswas, B.K. (1988). Genotype and environment interaction in faba bean. M. Sc. Thesis in Genetics and Plant Breeding, Bangladesh Agricultural University. pp. 1-40.

Cazzato, E., Tufarelli, V., Ceci, E., Stellacci, A.M. and Laudadio, V. (2012). Quality yield and nitrogen fixation of faba bean seeds as affectedby sulphur fertilization. Acta Agriculturae Scandinavica Section B-Soil and Plant Science. 62: 732738. https://doi.org/10.1080/09064710.2012.698642

Etemadi, F., Hashemi, M., Zandvakili, O. and Mangan, F. (2018). Phenology yield and growth pattern of faba bean varieties. International Journal of Plant Production. 12 (3): doi.org/ 10.1007/s42106-018-0023-1.

FAO (2021). FAOSTAT Database. Food and Agriculture Organization of the United Nations. Available at: www.fao.org/faostat/ [accessed April 15, 2021].

Fru"hbeck, G., Monreal, I. and Santidrian, S. (1997). Hormonal implications of the hypocholesterolemic effect of intake of field beans (Vicia faba L.) by young men with hypercholesterolemia. American Journal of Clinical Nutrition. 66: 1452-1460.

Gasim, S. and Link, W. (2007). Agronomic performance and the effect of soil fertilization on German winter faba bean. Journal of Central European Agriculture. 8: 121-127.

Gasim, S., Hamad, S.A.A., Abdelmula, A. and Ahmed, I.A.M. (2015). Yield and quality attributes of faba bean inbred lines grown under marginal environmental conditions of Sudan. Food Science and Nutrition. 3: 539-547.

Gupta, Y.P. (1987). Anti-nutritional and toxic factors in food legumes: a review. Plant Foods for Human Nutrition. 37: 201-228.

Hauggaard-Nielsen, H., Jørnsgaard, B., Kinane, J. and Jensen, E.S. (2008). Grain legume-cereal intercropping: The practical application of diversity, competition and facilitation in arable and organic cropping systems. Renewable Agriculture and Food Systems. 23: 3-12. 
Helsper, J.P., Hoogendijk, J.M., van Norel, A. and Burger-Meyer, K. (1993). Antinutritional factors in faba beans (Vica faba L.) as affected by breeding toward the absence of condensed tannins. Journal of Agriculture and Food Chemistry. 41: 1058-1061.

Hu, J., Kwon, S.J., Park, J.J., Landry, E., Mattinson, D.S. and Gang, D.R. (2015). LC-MS determination of L-DOPA concentration in the leaf and flower tissues of six faba bean (Vicia faba L.) lines with common and rare flower colors. Functional Foods in Health and Disease. 5: 243-250.

Hulse, J.H. (1994). Nature, Composition and Utilization of Food Legumes. In: Expanding the production and use of cool season food Legumes. [F.J. Muehlbauer and W.J. Kaiser (eds.)], Kluwer Academic Publishers, Dordrecht, The Netherlands. pp. 77-97.

Jambunathan, R., Blain, H.L., Dhindsa, K.H., Hussein, L.A., Kogure, K., Li-Juan, L. et al. (1994). Diversifying Use of Cool Ceason Food Legumes through Processing. In: Expanding the Production and Use of Cool Season Food Legumes. [F.J. Muehlbauer and W.J. Kaiser (eds.)], Kluwer Academic Publishers, Dordrecht, The Netherlands. pp. 98-112.

Jensen, E.S. and Hauggaard-Nielsen, H. (2003). How can increased use of biological $\mathrm{N}_{2}$ fixation in agriculture benefit the environment? Plant and Soil. 252: 177-186. https://doi. org/10.1023/A:1024189029226.

Karim, M.A., Quayyum, M.A.. Samsuzzaman, S., Higuchi, H. and Nawata, E. (2017). Challenges and opportunities in crop production in different types of char lands of Bangladesh: Diversity in crops and cropping. Tropical Agriculture and Development. 61(2): 77-93.

Kaletha, M., Bhatt, B.P. and Todaria, N.P. (1996). Allelopathic cropweed interactions in traditional agroforestry systems of Garhwal Himalaya. Allelopathy Journal. 3: 65-70.

Karkanis, A., Ntatsi, G., Lepse, L., Fernández, J.A., Vågen, I.M., Rewald, B., Alsin, I., Kronberga, A., Balliu, A., Olle, M., Bodner, G., Dubova, L., Rosa, E. and Savvas, D. (2018). Faba bean Cultivation- Revealing novel managing practices for more sustainable and competitive European cropping systems. Frontiers in Plant Science. 9:1115. https:// doi.org/10.3389/fpls.2018.01115.

Kaur, M. and Singh, N.A. (2007). A comparison between the properties of seed, starch, flour and protein separated from chemically hardened and normal kidney beans. Journal of Science Food Agriculture. 87: 729-737. https:/ /doi.org/10.1002/jsfa.2798.

Kumar, A., Nidhi, Prasad, N. and Sinha, S.K. (2015). Nutritional and antinutritional attributes of faba bean (Vicia faba L.) germplasms growing in Bihar, India. Physiology and Molecular Biology of Plants. 21: 159-162. https://doi.org/10.1007/s12298014-0270-2.

Link, W., Balko, C. and Stoddard, F.L. (2010). Winter hardiness in faba bean: Physiology and breeding. Field Crops Research. 115: 287-296. https://doi.org/10.1016/j.fcr.2008.08.004.

Luo, Y., Xie, W., Xie, C., Li, Y. and Gu, Z. (2009). Impact of soaking and phytase treatments on phytic acid, calcium, iron and zinc in faba bean fractions. International Journal of Food Science and Technology. 44: 2590-2597. https://doi.org/ 10.1111/j.1365-2621.2009.02089.x.
Luo, Y-W. and Xie, W-H. (2013). Eûect of diûerent processing methods on certain antinutritional factors and protein digestibility in green and white faba bean (Vicia faba L.). CYTA- Food. 11: 43-49. https://doi.org/10.1080/19476337. 2012. 681705.

Madar, Z. and Stark, A.H. (2002). New legume sources as therapeutic agents. British Journal of Nutrition. 88: 287-292. https:/ /doi.org/10.1079/BJN2002719.

Martin, A., Cabrera, A. and Medina, J.L. (1991). Antinutritional factors in faba bean. Tannin content in Vicia faba: possibilities for plant breeding. Options Méditerranéennes-Série Séminaires. 10: 105-110.

Mandal, U.K., Singh, G., Victor, U.S. and Sharma, K.L. (2003). Green manuring: Its effect on soil properties and crop growth under rice-wheat cropping system. European Journal of Agronomy. 19: 225-237. https://doi.org/10.1016/S11610301(02)00037-0.

Meradsi, F. and Laamari, M. (2016). Aphicidal and behavioral effects of Vicia faba L. (Fabales: Fabaceae) leaf extracts against Aphis fabae Scopoli (Hom., Aphididae). Jordan Journal of Agricultural Sciences. 12: 1085-1094.

Merga, B., Egigu, M.C. and Wakgari, M. (2019). Reconsidering the economic and nutritional importance of faba bean in Ethiopian context. Cogent Food and Agriculture. 5: 6839 38.https://doi.org/10.1080/23311932.2019.1683938

Mona, A.M., Sabah, M.A. and Rehab, A.M. (2011). Influence of potassium sulfate on faba bean yield and quality. Australian Journal of Basic and Applied Sciences. 5: 87-95.

Mortuza, M.G., Hannan, M.A. and Tzen, J.T.C. (2009). Chemical composition and functional properties of Vicia faba L. Bangladesh. Bangladesh Journal of Botany. 38: 93-97. https://doi.org/10.3329/bjb.v38i1.5129

Multari, S., Stewart, D. and Russell W.R. (2015). Potential of fava bean as future protein supply to partially replace meat intake in the human diet. Comprehensive Reviews in Food Science and Food Safety. 14: 511-522. https:// doi.org/10.1111/1541-4337.12146

Murinda, M.V. and Saxena, M.C. (1985). Agronomy of Faba Beans, Lentils and Chickpeas. In: Proceedings of the International Workshop on Faba Beans, Kabuli Chickpeas and Lentils in the 1980s. ICARDA, [M.C. Saxena and S. Verma (eds.)], 16-20 May, 1983. Aleppo, Syria. p. 229-244.

Nadal, S., Suso, M. and Moreno, M. (2003). Management of Vicia faba genetic resources: changes associated to the selfing process in the major, equina and minor groups. Genetic Resources and Crop Evolution. 50: 183-192. https:// doi.org/10.1023/A:1022944017530.

Nuessly, G.S., Hentz, M.G., Eiriger, R.B. and Scully, B.T. (2004). Insects associated with faba bean, Vicia faba (fabales: fabaceae), in southern Florida. Florida Entomologist. 87(2): 204-211. https://doi.org/10.1653/0015-4040 (2004) 087[0204:IAWFBV]2.0.CO;2

Nava-Rodriguez, V., Hernandez-Bautista, B.E., Cruz-Ortega, R. and Anaya, A.L. (2005). Allelopathic potential of beans (Phaseolus spp.) and other crops. Allelopathy Journal. 15: 197-210. 
Faba Bean (Vicia faba L.), A Promising Grain Legume Crop of Bangladesh: A Review

O’Donovan, J.T., Grant, C.A., Blackshaw, R.E., Harker, K.N., Johnson, E.N., Gan, Y., Lafond, G.P., May, W.E., Turkington, T.K., Lupwayi, N.Z., Stevenson, F.C., McLaren, D.L., Khakbazan, M. and Smith, E.G. (2014). Rotational effects of legumes and non-legumes on hybrid canola and malting. Agronomy Journal. 106: 1921-1932. https://doi.org/10.2134/agronj 14.0236.

Oplinger, E.S. (1982). Faba beans Field Crops 32.0 UWEX. Madison, WI 53706.

Oshodi, A.A. and Adeladun, M.O.A. (1993). Proximate composition, some nutritionally valuable minerals and functional properties of three varieties of lima bean (Phaseolus lunatus L.). International Journal of Food Science Nutrition. 43: 181-185. https://doi.org/10.3109/096374893090275 40

Papadopoulou, A. and Frazier, R.A. (2004). Characterization of protein-polyphenol interactions. Trends in Food Science and Technology. 15: 186-190. https://doi.org/10.1016/j. tifs.2003.09.017.

Patil, S.A., Apine, O.A., Surwase, S.N. and Jadhav, J.P. (2013). Biological sources of L-DOPA: an alternative approach. Advances in Parkinson's Disease. 2: 81-87. https://doi. org/10.4236/apd.2013.23016.

Paul, S.K., Mondal, M., Sarker, U.K. and Sarkar, S.K (2021). Response of yield and seed quality of faba bean (Vicia faba) to irrigation and nutrient management. Research on Crops. 22(2): 256-264. https://doi.org/10.31830/23487542.2021 .066 .

Peyvast, G. and Khorsandi, Z. (2007). Antibacterial activity of the broad bean extracts on resistant bacteria. Pakistan Journal of Biological Sciences. 10(3): 398-402. https:// doi.org/ 10.3923/pjbs.2007.398.402.

Proskina, L. and Cerina, S. (2017). Faba beans and peas in poultry feed: economic assessment. Journal of the Science of Food and Agriculture. 97: 4391-4398. https://doi.org/ 10.1002/jsfa.8415.

Ramirez-Moreno, J.M., Salguero Bodes, I., Romaskevych, O. and Duran-Herrera, M.C. (2015). Broad bean (Vicia faba) consumption and Parkinson's disease: A natural source of L-dopa to consider. Neurologia. 30: 375-376. https:// doi.org/10.1016/j.nrl.2013.08.006.

Rubiales, D. and Mikic, A. (2015). Introduction: Legumes in sustainable agriculture. Critical Reviews in Plant Sciences. 34: 1-3. https://doi.org/10.1080/07352689.2014.897896.

Rubio, L.A., Grant, G., Dewey, P., Bremner, I. and Pusztai, A. (1994). The intestinal true absorption of $\mathrm{Zn}$ in rats is adversely affected by diets containing a faba bean (Vicia faba L.) nonstarch polysaccharide fraction. The Journal of Nutrition. 124: 2204-2211. https://doi.org/10.1093/jn/124.11.2204

Salahin, N., Alam, M.D.K., Islam, M.D.M., Naher, L. and Majid, N.M. (2013). Effects of green manure crops and tillage practice on maize and rice yields and soil properties. Australian Journal of Crop Science. 7: 1901-1911.

Sathe, S.K., Deshpande, S.S. and Salunkhe, D.K. (1982). Functional properties of lupin seeds (Lupinus mutabilis) proteins and protein concentrates. Journal of Food Science. 47: 491-497.
Sheikh, M.A.K., Paul, S.K. and Sarkar, M.A.R. (2020). Effect of spacing and Rhizobium inoculum on the yield and quality of faba bean (Vicia faba L.). Journal of Bangladesh Agricultural University. 18(2): 245-251. https://doi.org/ 10.5455/JBAU. 91870.

Shi, L., Mu, K., Arntûeld, S.D. and Nickerson, M.T. (2017). Changes in levels of enzyme inhibitors during soaking and cooking for pulses available in Canada. Journal of Food Science and Technology. 54: 1014-1022. doi: 10.1007/s13197017-2519-6.

Sillero, J. C., Villegas-Fernandez, A.M., Thomas, J., Rojas-Molina, M.M., Emeran, A.A., Fernandez Aparicio, M. and Rubiales, D. (2010). Faba bean breeding for disease resistance. Field Crop Research. 115: 297-307. https://doi.org/10.1016/ j.fcr.2009.09.012

Singh, A.K. and Bhatt, B.P. (2012a). Faba Bean (Vicia faba L.): A potential leguminous crop of India ISBN 978-93-5067773-5ICAR, RC for ER, Patna, P. 518.

Singh, A.K. and Bhatt, B.P. (2012b). Faba bean: unique germplasm explored and identified. Hort Flora Research Spectrum. 1(3): 267-269.

Singh, A.K., Bharati, R.C., Manibhushan, N.C. and Pedpati, A. (2013). An assessment of faba bean (Vicia faba L.) current status and future prospect. African Journal of Agricultural Research. 8: 6634-6641.

Singh, A.K., Bhatt, B.P., Upadhyaya, A., Kumar, S., Sundaram, P.K., Singh, B.K., Chandra, N. and Bharat, R.C. (2012). Improvement of faba bean (Vicia faba L.) yield and quality through biotechnological approach: a review. African Journal of Biotechnology. 11: 15264-15271. https://doi.org/10.5897/ AJB12.1926.

Sinha, S.K. (2012). Faba bean: a potential alternative grain legume of future. Rashtriya Krishi. 7: 45-46.

Sinha, S.K., Kumar, M., Kumar, A., Bharti, S. and Shahi, V.K. (2013). Antioxidant activities of different tissue extract of Faba bean (Vicia faba L) containing phenolic compounds. Legume Research. 36: 496-504.

Shukla, U.N. and Mishra M.L. (2020). Present scenario, bottlenecks and expansion of pulse production in India: A review. Legume Research. 43 (4) 461-469. https://doi.org/10.18805/LR3998.

Subedi, B., Acharya, K. and Kafle, K. (2018). Effectiveness of plant leaf extract on black bean aphid (Aphis fabae Linn.). Innovative Techniques in Agriculture. 2(3): 395-399.

Surwase, S.N., Patil, S.A., Jadhav, S.B. and Jadhav, J.P. (2012). Optimization of L-DOPA production by Brevundimonas sp. SGJ using response surface methodology. Microbial Biotechnology. 5: 731-737. https://doi.org/10.1111/j.17517915.2012.00363.x

Turco, I., Ferretti, G. and Bacchet, T. (2016). Review of the health benefits of Faba bean (Vicia faba L.) polyphenols. Journal of Food and Nutrition Research. 55(4): 283-293.

Upadhyay, V., Muntean, B., Hwang, J., Kathem, S., Abou-Alaiwi, W. and Nauli, S. (2014). Roles of dopamine receptor on chemosensory and mechanosensory primary cilia in renal epithelial cells. Frontiers in Physiology. 5: 72. https:// doi.org/10.3389/fphys.2014.00072. 
Wissal, M., Nadia, K. and Haythem, M. (2020). Legumes: Model plants for sustainable agriculture in phosphorus and iron deficient soils. Agricultural Science Digest. 40(4): 445447. https://doi.org/10.18805/ag.D-24e.

Witten, S., Böhm, H. and Aulrich, K. (2015). Effect of variety and environment on the contents of crude nutrients, lysine, methionine and cysteine in organically produced field peas (Pisum sativum L.) and field beans (Vicia faba L). Landbauforsch Volkenrode. 65: 205-216. https://doi.org/ 10.3220/LBF1447765843000.

Yadav, S.K., Verma, N., Singh, A.K., Singh, N., Rana, S.C., Ranga S.S. and Kumar, K. (2017). Diversity and development in faba bean. Legume Research. 40(4): 618-623. https:/ /doi.org/10.18805/Ir.v0iOF.6200.
Yasmin, W., Paul, S.K. and Anwar, M.P. (2020). Growth, yield and quality of faba bean (Vicia faba L.) in response to sowing date and phosphorus fertilization. Archives of Agriculture and Environmental Science. 5(1): 11-17. https:// dx.doi.org/10.26832/24566632.2020.050102.

Yitayih, G. and Azmeraw, Y. (2017). Adaptation of faba bean varieties for yield, for yield components and against faba bean gall (Olpidium viciae Kusano) disease in South Gondar, Ethiopia. The Crop Journal. 5: 560-566. https://doi.org/ 10.1016/j.cj.2017.05.007. 